\title{
Distributed Leadership in Transformation Initiatives: The Emergence of Network Leadership
}

\author{
Nawaf H Al-Ghanem \\ $\mathrm{PhD}$ Researcher \\ Business School \\ Brunel University London \\ London, Uxbridge, UK \\ E-mail: nawaf.alghanem@brunel.ac.uk \\ Ashley Braganza $P h D$ \\ Professor \\ Business School \\ Brunel University London \\ London, Uxbridge, UK \\ E-mail: Ashley.braganza@brunel.ac.uk \\ Esra Aldhean $P h D$ \\ Assistant Professor \\ Business School \\ Ahlia University \\ Manama, Bahrain \\ E-mail: esaldhean@ahlia.edu.bh
}

\begin{abstract}
Several research studies investigated organizational transformation in particular to examine various leadership theories and styles that emerged during different chronological evolution of leadership theories. In similar context, attention has been given recently to collective/team leadership theories that depend on more collective approach to leadership. Examining organizational transformation literature and leadership theory literature is expected to lead to identifying an intersection between these important topics. This paper intends to bridge distributed leadership theory and organizational transformation theory in achieving efficient and optimal results when implementing large scale organizational transformational initiatives and examining the notion of network leadership by overlaying social network theory to the characteristics of distributed leadership, which is expected to add to the current knowledge and use by scholars and policy makers while practicing leadership in a organizations going through transformation.
\end{abstract}

Keywords: Organizational Transformation, Leadership Theory, Team/Collective Theory, Distributed Leadership, Social Network Theory, Actor Network Theory.

\section{Introduction}

\section{I.I Introduce the Problem}

The concepts of Leadership are envisaged as a tough challenge in the world economy characterized by business environment, which is termed as vibrant, energetic and competitive. Handling such competitive economic environment would essentially require organizations to transform and go through organizational transformations to be able to cope with business trends (Mikalef et al., 2018). International markets and geopolitics environment feverishly evoke organizations, whether large or small in size to implement changes and modify the way they perform businesses, or even the way they change their organizational cultures and beliefs. In the current business environment, a crucial contingent upon how organization can manage to cope with change, especially those changes generated from strategic decisions (Levene \& Braganza, 1996). Studies also investigated environmental changes that force organizations to adapt new strategies and transform in order to sustain (Aldhaen, 2017). The process of organizational change is an obligation for organizations to survive and prosper. 
The great majority of organizations compete by changing incessantly (Brown \& Eisenhardt, I997; Weick \& Quinn, 1999). There is one approach with which leader can adopt to create a competitive advantage; that is to nurture an organizational climate which promotes change. Organizations that are dynamic towards adapting to the environmental changes are found to be better positioned to survive tough environment (Henderson \& Clark, I990; Mikalef et al, 2018).

Organisational transformation is seen a whole process which depends on the efficiency and success of these changes which depend on the way they are carried out and presented to organizations population (AlGhanem et al., 20I9). Implementation of appropriate organizational changes largely depends on the effectiveness of leadership. Generally speaking, leaders and followers are major components to competent implantation of change (Kempster et al., 20I4; Gaub et al., 2016). Since the leadership concept attracts growing interest of many researchers, several theories and studies have been published and various of leadership styles have evidently evolved.

This paper will mainly focus on the key significance of team/collective leadership theory as an essential aspect of change management that results in achieving incessant performance and relationship improvements during the process of organizational change. In fact, the purpose of this research is to explore its impact on achieving results during organizational change. This study will additionally investigate into the need of implementing different social network leadership approaches to enhance performance and ensure collective changes when organizations go through transformation phase.

Furthermore, will provide a research background supported by an extensive literature review related to organizational changes and distributed leadership theory. The paper largely focuses on the relation between organizational change and leadership theory. Based on the analysis of the literature findings, this paper will propose a research model that will handle potential areas for future research.

\section{I.2 Research Problem}

Organisational change is certainly a vital process where leadership style and leaders are the tools of implementing those changes effectively, incessantly, consistently and precisely. However, the dilemma of which leaders and leadership styles should be applied as a means of implementing those changes still exists. Unquestionably, numerous studies, researches and scholars had arguments and disputes in defending different leadership styles (Brown \& Eisenhardt, 1997; Weick \& Quinn, 1999; Feldman \& Pentland, 2003). Those arguments and disputes have led to creating vibrant connections between several schools of thoughts as some still believe in old approaches of leadership while others advocate for new trendy leadership styles. A large number of researchers highlighted the significance of having change leadership to alleviate tension and smoothen the efficient performance of employees (Bass \& Riggio, 2006; Pawar \& Eastman, 1997).

Opposite to traditional leadership approaches, team/collective leadership would widely necessitate executive's engagement, empowerment and easing to connect and interconnect disparate organizational elements (AlGhanem et al., 20I9). According to (Ribera et al., 200I; Bryk, 2002) that proper implementation of changes should be executed through different and various leadership styles and schools. Making the best use of these leadership styles and theories should have positive and encouraging impact, boosting performance, and implementing most desired ceaseless changes imposed by stakeholders and board members.

This paper intends to argue if distributed leadership would achieve further enhancement towards maximizing the implementation of organizational changes by overlaying to examine the notion of network leadership which is an extension of previous study by (AlGhanem et al., 2019).

\section{Research Background}

Organisational change is certainly a vital process where leadership style and leaders are the tools of implementing those changes effectively, incessantly, consistently and precisely. However, the dilemma of which leaders and leadership styles should be applied as a means of implementing those changes still exists. Unquestionably, numerous studies, researches and scholars had arguments and disputes in defending different leadership styles (Brown \& Eisenhardt, 1997; Weick \& Quinn, I999; Feldman \& Pentland, 2003). Those arguments and disputes have led to creating vibrant connections between several schools of thoughts as some still believe in old approaches of leadership while others advocate for new trendy leadership styles. A large number of researchers highlighted the significance of having change leadership to alleviate tension and smoothen the efficient performance of employees (Bass \& Riggio, 2006; Pawar \& Eastman, 1997).

Opposite to traditional leadership approaches, team/collective leadership would widely necessitate executive's engagement, empowerment and easing to connect and interconnect disparate organizational elements (AlGhanem et al., 20I9). According to (Ribera et al., 200I; Bryk, 2002) that proper implementation of changes should be executed through different and various leadership styles and schools. Making the best use of these leadership styles and theories should have positive and encouraging impact, boosting performance, and implementing most desired ceaseless changes imposed by stakeholders and board members. 
This paper intends to argue if distributed leadership would achieve further enhancement towards maximizing the implementation of organizational changes by overlaying to examine the notion of network leadership which is an extension of previous study by (AlGhanem et al., 2019).

\section{Literature Review \\ 3.I Organisational Transformation}

Organizational transformation is in fact an organizational change which largely goes beyond the concept of a mere change in systems to a process that goes deeply into various organizational layers in order to achieve extreme satisfaction and inspiring insight of the organization's aspired goals and objectives. Generally speaking, one of the major definitions of organizational change is a term which refers extensively to such activities as re-engineering, redesigning and refining operational systems or a change in the manner the business is implemented in the event of the re-engineering or the restructuring activity. However, some studies of corporate transformation argue that growing, incremental additional capabilities need to be further combined increasingly by establishments in order to transform or "rejuvenate" themselves (Francis et al., 2003). Organizational transformation is often termed as either incremental or radical. In similar context, Morris and Brandon confirm that organizations should carefully place their re-engineering (redesign) projects alongside other change initiatives and schemes which place including total quality, redesign and empowerment. Furthermore, Hamstra (2014) argues that organizations which have implemented incremental changes, can generally improve what was done earlier by changing a single variable, within the functional structure. In today's economy competitive organizations are those who are able to adapt to markets changing environment and global economy and are capable to transform themselves by making deep organizational layer changes. It is evident that the main mainstay of the organizations is its ability to satisfy its needs (Karimuribo et al., 2006). However, transformation is observed as an all-pervading, universal, and multi-layered process within a specific business frame and presents immense and massive challenges to any system (Beckhard, 2006). The challenge of organizational transformation in complex business patterns would principally require deep insight of theoretical examination, such as exploring probable mixtures of individual and plural outlooks of leadership at the peak of the organization (Sergi et al., 2012). Yet the literature continues to focus widely on the individual who leads the transformation process, rather than on the plurality of individuals and their interactions (Kempster et al., 2014; Gaub et al., 2016). Transformation is in fact a facilitation of radical shift in the organization values, culture, structure, routine and how business is carried out (Bartunek \& Louis, 1988).

As discussed above this paper considers organizational transformation as the major instrument for organizations both private and public to enhance not only their productivity but improve efficient performance and internal satisfaction of individuals. The key significance of organizational change and transformation emerges from the necessity to cope with and smoothen the way business is carried out through those changes. With organizational change the issue of having a combination of leadership styles and approaches to lead the organization towards achieving those changes is raised. Organizational transformation can generally take many numerous forms from radical to incremental to continuous (morphing). Each form of transformation would actually require various mixtures of leadership styles.

The oil and gas sector are one of the sectors that largely depends on those new technologies to adapt to market demands and be able satisfy customers with products which fully and successfully meet international specifications. Indeed, organizations operating in such dynamic and vibrant environment need to go through organizational transformation both incessantly (morphing) and radically to maintain their competitive edge.

\subsection{Leadership Theory}

Figure I below describes in short brief the chronological evolution and development of leadership theory through time. As the focus of this paper is towards the newer team/collective approach to leadership rather than discussing earlier leadership theories that has been researched and studies by scholars.
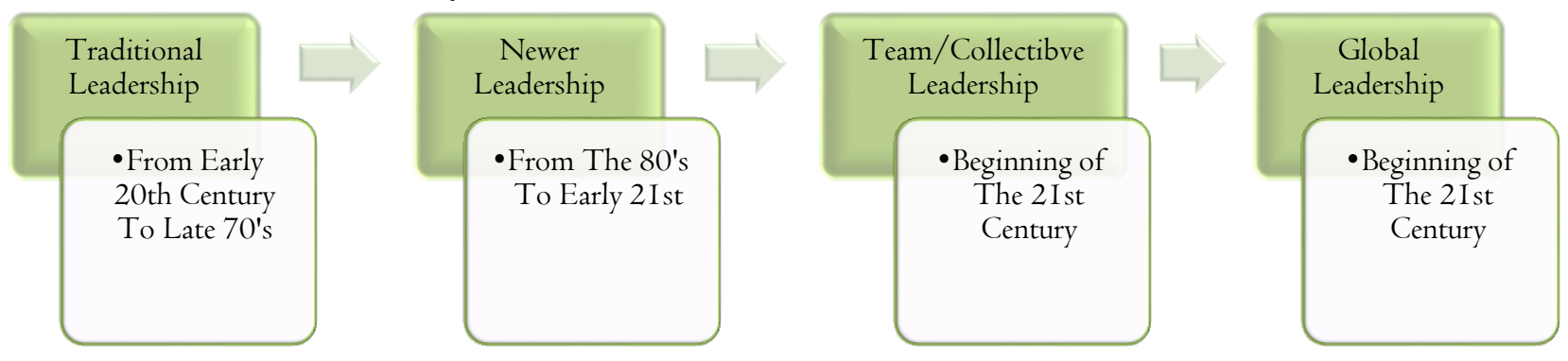

Figure I. Chronological evolvement of leadership theory. 
Leadership is, nevertheless termed by scholars and researchers as traditional and newer leadership theories. Leadership theories which are traced back from the early twentieth century to the late seventies are generally referred to as traditional leadership theories, which widely emerged and developed from the eighties to early twenty first century where they are identified as newer leadership theories (Avolio et al., 2009). In fact, at the outset of this century more collective and team focused leadership started evolving and developing alongside the new evolutionary global leadership theory which has emerged recently. However, as discussed previously that this paper intends to focus on newer leadership theories. Leaders' characteristics can result in better implementation of the transformation initiatives taken by the organization (Higgs \& Rowland, 20I I). Many leadership theories which have emerged and evolved during the last century have undergone major modifications to meet the changing volatility of the business environment. Nonetheless, this research study aims to briefly review the various types of traditional, newer, team/collective and global leadership theories which is explained within the following sections.

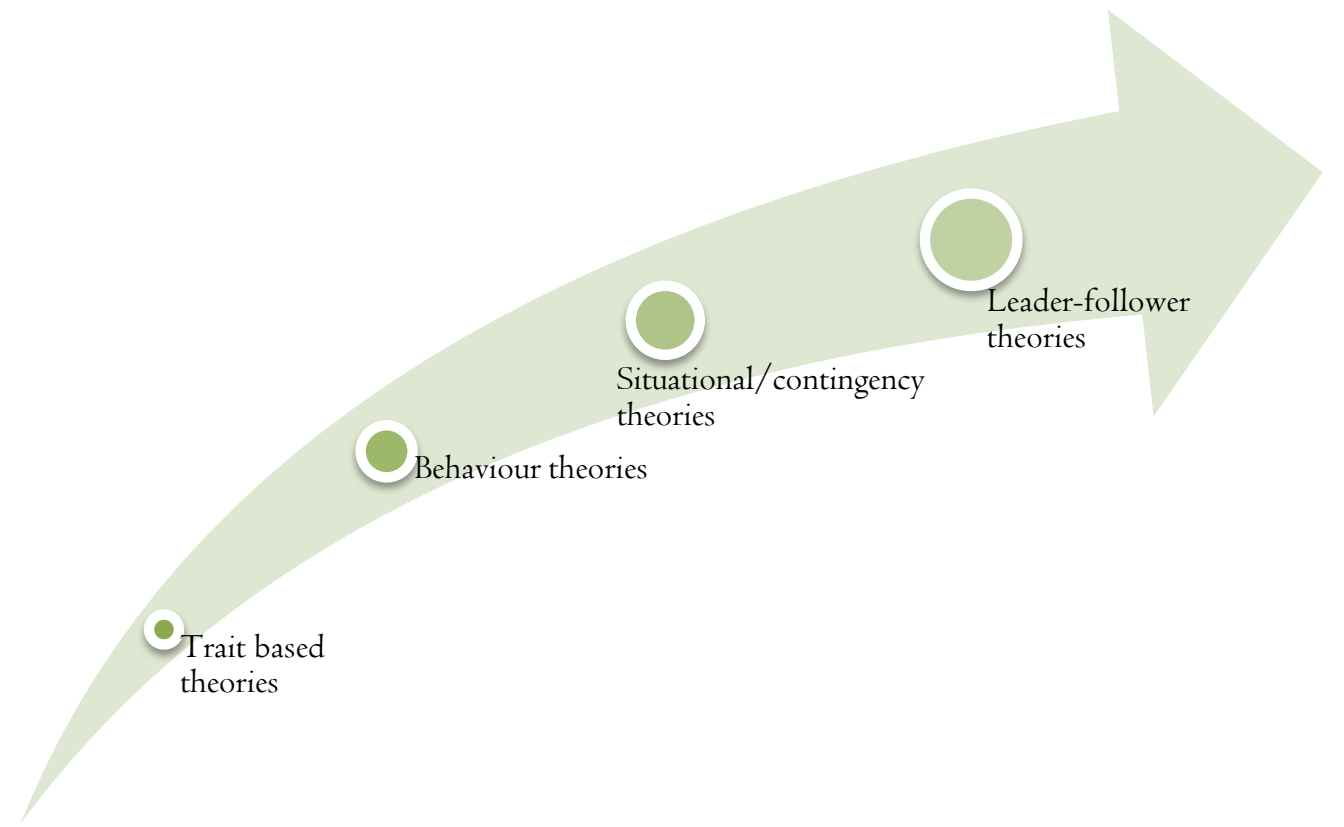

Figure 2. Traditional leadership development.

\subsection{Collective/Team Leadership Theory}

Collective or team leadership theory is an approach to leadership which leverages on the human aspects focusing on induvial and encouraging their positive participation in decision-making process (Arredondo Trapero et al., 20I0). Collective approaches to leadership are built around the concept of moving from a single leadership to a leadership model where "followers and groups exercise shared leadership to initiate transformative change" (Eberly et al., 2013). Collective/team leadership theories are decentralized where leadership can be rotated or shared based on the situation and current challenge facing the organization, operating at multilevel, formal/informal and dynamic in its approach to leadership as leaders are encouraged to be proactive in their leadership (Friedrich \& Elias, 2014).

As described above many researchers has been bridging leadership theory with result related to organizational satisfaction, effectiveness and organizational behavior (Bass \& Avolio, I994; Detert \& Burris, 2007; Carter et al., 2015). Researches stressed that the concept of leadership is only executed by a single leader in a traditional approach to leadership (Pearce \& Conger, 2003). As a natural evolvement of post-heroic leadership theory interest started emerging during the mideighties in more shared, distributed, collaborative and collective leadership theory where leadership is shared between a group of leaders. This evolvement in leadership theory focused on the relationship between different components and elements of the organization from induvial to organizational bodies ensuring the achievement of the collective goals smoothly in coordination and harmony (Kickert et al., I997). As a natural development in the field of leadership studies interest around intra and interorganizational leadership started growing alongside the continuing interest in traditional hierarchal approach to leadership. Based on this natural development in the mind set of researchers the concept of collective/team leadership emerged and was acknowledged as a new approach to organizational leadership (Bryson \& Thompson, 1978). Approaching leadership as networks in combination with traditional leadership styles results in positive performance and high levels of organizational change execution during the organizational transformation. 
Table I. Difference between organizational and social network leadership

\begin{tabular}{ll}
\hline Organizational Leadership & Social Network Leadership \\
\hline Position, authority & Role, behaviour \\
\hline Individual & Collective \\
\hline Control & Facilitative \\
\hline Directive & Emergent \\
\hline Transactional & Relational, connected \\
\hline Top-down & Bottom-up \\
\hline
\end{tabular}

Source: Monitor Institute SlideShare, Social Networks for Social Change (p.72)

Collective leadership is commonly known as shared leadership but academically known as leadership networks (Carter et al., 2015). Teams engaged in complex decision making or knowledge-based works highly benefits from such approach to leadership (Fausing et al., 2013). The sharing of leadership roles results in performance efficiency during organizational transformation in networks with formal or informal leadership (Wang et al., 20I4). Leadership as Network approach has many constructs of leadership styles. The closest and most common definition by researchers of collective/team leadership defined as an approach to leadership in an unconventional way where leadership is down-top, collective, distributive, collaborative, facilitative and functional. Another definition is that "leadership as network is executed in a network setting by one or more network actors or externals in which the precise leadership role and its distribution are heavily dependent upon the context" (Wind, 2017).

Leadership theory has moved along and went through many instrumental changes in believes and practices since the traditional heroic and great mean theories to newer leadership theories (charismatic, inspirational, transactional and transformational) towards more collective models. Leadership as network is a systematic thinking leadership that takes leadership theory to the next level by applying more collective and collaborative approaches throw connecting the wieldy mass of disparate elements of the organization or organizations and distributing leadership responsibilities among network members. With developments in the field of leadership and the importance of relations between deferent parts of the organizational and Interorganizational relations the theory addressing changes across organizations and focusing on how organizations work together emerged. Based on the premise that collaboration among community organizations leads to more comprehensive coordinated approach to a complex issue that can be achieved by organizations (Kickert et al., I997; Levine \& White, 1961). Developments in society as well as the economy underline the importance of not only understanding leadership in organizations, but also within broader context 'networks' (Wind, 2017).

Team/collective approach to leadership was first recognized and acknowledged as a political approach to leadership in organizational networks (Bryson \& Thompson, 1978). There are different definitions and terms for network leadership however almost all scholars agree to number of characteristics and properties of the approach of network to leadership. First, leadership is argued to be relational. The relational view and approach to leadership was adopted by (Hollander \& Julian, 1969). Progression towards relational approach to leadership has exhibited increasing importance of sharing and collective leadership. Second, leadership and how it's perceived is largely inseparable from the situation in which it occurs (Wagner III \& Hollenbeck, 20I4). Therefore, leadership is situated in its context (Carter et al., 2015; Wind, 2017). Third, leadership is patterned and uniquely developed between different dyads due to experiences, processes and context (Carter et al., 2015; DeRue, 20II; Lord et al., 200I). Forth, leadership can be both formal and informal (Follet et al., I925).

As stated above and emphasized by researchers the need of collective approach to leadership is by multiple or group of induvial is a necessity to face increasing challenges and problems through formal or informal engagement. Shared, distributed, complex, democratic, intergroup, collaborative, participative, collective leadership and social network theory are all team/collective leadership elements that forms and structures the network leadership that highlights and defines the spectrum of this leadership theory.

Researches and studies conducted on leadership as networks has highlighted that network approach to leadership strengthen information sharing, team effectiveness, and as a result leads to better performance (Hoch, 20I3). This approach to leadership is very instrumental to teams and groups engaged in sophisticated complex and knowledge-based environments that requires high levels of interaction, innovation, and performance (Wang et al., 20I4; Fausing et al., 2013). As studies conducted by researchers showed that teams how operated in those environments that has positive strong relations between team members and teams, empowerment of members participating in leadership activities (Carson et al., 2007; Fausing et al., 2013) develop complex network leadership structures. 
Network leadership can be defined as a process of emergent relationship between induvial, team members (actors) and networks that interacts with each other sharing leadership role between each other to achieve the overall collective goal of the organizational in a systematic way (Carter et al., 2015; Small \& Rentsch, 20II). Network leadership theory is dynamic in interaction between leaders and followers exchanging knowledge, experience, information within a wider organizational network, and congenitally multilevel in its structure of networks (actors) (Carter et al., 2015).

Researchers has used different terms describing the newer emerging non-hierarchical views of leadership in terms such as shared leadership (D’Innocenzo et al., 2016; Wang et al., 20I4) distributed leadership (Gronn, 2002; Spillane, 20I2) collective leadership ...etc. This research also considers social network theory and actor network theory to have an overall understanding of network leadership and the way networks operates, interacts, and functions. There is a need to have a better understanding on how a network or a group networks interact with each other will provide us with netter insight of the expected outcome and its impact on the organizational goal achievement. This research paper will also sight network leadership theory from social network theory and actor network theory to have a better understanding of the network leadership concept and its operating mechanism table 2 indicates a comparison between traditional leadership and team/collective leadership.

Table 2. Traditional vs Team/Collective leadership

\begin{tabular}{lll}
\hline & Traditional leadership & Team/Collective leadership \\
\hline Organisational view & Looked at as machines. & Looked at as a systematic process. \\
\hline Structure & Vertical hierarchal & Network of individuals or teams \\
\hline Decision & Vertical top-down & Shared, distributed and rotated \\
\hline $\begin{array}{l}\text { Induvial capacity } \\
\text { assumption }\end{array}$ & Individuals are ordered & $\begin{array}{l}\text { Individuals are capable and trusted to perform. } \\
\text { Success creation }\end{array}$ \\
$\begin{array}{l}\text { Only one individual has the trait and skill } \\
\text { to be successful }\end{array}$ & $\begin{array}{l}\text { From the collective and cumulative skills } \\
\text { and characteristics of team members }\end{array}$ \\
\hline
\end{tabular}

\subsubsection{Collective/Team Leadership Dimension Constructs}

This section will be discussing the different constructs and elements of collective/team leadership from shared leadership to social network theory which are the two extremes of the wide spectrum of team/collective leadership approach to leadership.

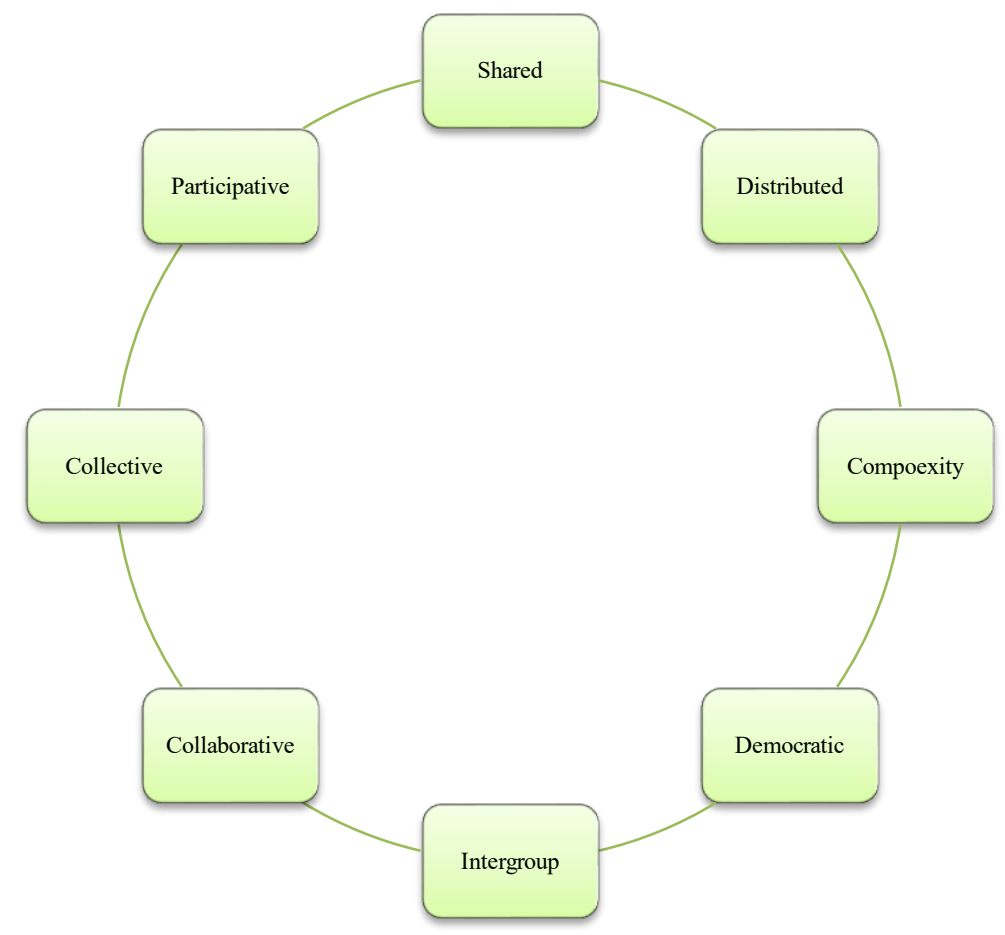

Figure 3. Collective/team leadership dimension constructs. 


\subsubsection{Shared Leadership}

Shared leadership is the most common and known construct/element of team/collective leadership which is defined as "a dynamic interactive influence process among individuals in groups for which the objective is to lead one another to the achievement of group or organizational goals, or both” (Pearce \& Conger, 2003, p.I). Shared leadership has emerged due to the shifts in the global and local business environment alongside the organizations increasing complexity and ambiguity (Gronn 2003). In such complex situations, it is assumed that leaders are not provided with sufficient or accurate information to take decisions in such volatile and complex environment (Pearce \& Conger, 2003). Therefore, the term of shred leadership emerged as a solution for such situations by sharing leadership between leaders with different expertise and talents (Seers et al., 2003). The process of shared leadership occurs when team members tend to exchange the leadership role frequently and intentionally between each other according to the trait and qualification needed to lead through a precise environment circumstance or a certain operational need such as organizational transformation or management change initiatives. As (Pearce \& Conger, 2003) stated that "ever more difficult for any leader from above to have all of the knowledge, skills and abilities necessary to lead all aspects of knowledge work" (p.I32). Many studies have highlighted the positive impact and influence of shared leadership and debated that it leads to more efficient and higher performance levels when compared with traditional hierarchical leadership structures (Avolio et al., 1996; Carson et al., 2007; Perry et al., 1999). However, few studies argued that the extent to which shared leadership is related to positive team performance and therefore it is not yet clear (Bowers \& Seashore, I966).

Table 3. Shared leadership definitions

\begin{tabular}{|c|c|c|}
\hline & Definition & Author \\
\hline $\mathrm{I}$ & $\begin{array}{l}\text { "Collective influence of members in a team on each other and how } \\
\text { members of a group evaluate the influence of the group as opposed to } \\
\text { one induvial within or external to the group" }\end{array}$ & Sivasubramaniam et al., 2002 \\
\hline 2 & $\begin{array}{l}\text { "Leadership can be shared over time whereby team members share in } \\
\text { responsibilities involved in the leadership role by clarifying who is to } \\
\text { perform specific role behaviors" }\end{array}$ & Erez et al., 2002 \\
\hline 3 & $\begin{array}{l}\text { "Team process where leadership is carried out by the team as a whole } \\
\text { rather than solely by a single designated individual" }\end{array}$ & Ensley et al., 2006 \\
\hline 4 & $\begin{array}{l}\text { "Shared, distributed phenomena in which there can be several (formally } \\
\text { appointed and/or emergent) leaders" }\end{array}$ & Mehra et al., 2006 \\
\hline 5 & $\begin{array}{l}\text { "An emergent team property that results from the distribution of } \\
\text { leadership influence across the multiple members" }\end{array}$ & Carson et al., 2007 \\
\hline 6 & $\begin{array}{l}\text { "Team's capability for collectively engaging in transformational } \\
\text { leadership behaviors; leadership as a collective process, such the team } \\
\text { influences, inspires, and motivate team members" }\end{array}$ & Gupta et al., 20I I \\
\hline 7 & $\begin{array}{l}\text { "The distribution of leadership influence across multiple team } \\
\text { members" }\end{array}$ & Zhou, 2012 \\
\hline
\end{tabular}

Researchers defined the boundaries and limits of shared leadership by defining the complex adaptive process that occurs between leaders and followers in teams (DeRue, 20II). Studies on shared leadership have found positive relationship between shared/multiple leadership and team performance with more efficiency and sustainability (Avolio et al., I996; Hoch \& Kozlowski, 2014) and a more accurate predictor of performance than vertical leadership (Ensley et al., 2006; Pearce \& Conger, 2003). This type of leadership is total deviation from the traditional concept of hierarchical leadership where decision making is directed flows downstream from leaders to followers (Day \& O'Connor, 2003; Pearce \& Conger, 2003). Shared leadership is a fundamental diversion from the idea of unified command in teams/groups (Wren et al., 2002) towards an emergent and a dynamic process (Sergi, et al., 2012).

\subsubsection{Distributed Leadership}

Distributed leadership is another construct/element of team/network leadership and is usually discussed with shared leadership (Gronn, 2008; Mehra et al., 2006). Distributed leadership is conceptualized as a concretive and conjoint effort of a group or network of individuals (Cirre et al., 2009; Bennet et al., 2003; Gronn, 2002). Unlike shared leadership focus solely on team level, distributed leadership identifies a focal designated leader and focuses on organization as whole rather than just team level (Fitzgerald et al., 2013; Currie et al., 20I I; Bolden, 2007). Distributed leadership has become a popular 'post-heroic' leadership style (Badaracco, 200I). 
Distributed leadership is a unit of analysis in which leadership could be understood in a holistic view rather than the form of induvial contributions (Gronn, 2002). Distributed leadership implementation was mainly in education and health sector (Bolden, 2007; Currie et al., 20II). Until the study of (Gronn's, 2002) which linked the concept distributed leadership to management organizational studies.

Distributed leadership emphasizes how human cognition is both held between individuals and aspects of the situation and thus cognitive activity is stretched over both human actors and aspect of the context they are in (Fitzsimons et al., 20I I).

Table 4. Distributed leadership advantage and disadvantages

\begin{tabular}{lll}
\hline Advantage & Disadvantage \\
\hline I & $\begin{array}{l}\text { More people are engaged in } \\
\text { decision making }\end{array}$ & $\begin{array}{l}\text { Accountability issues due to } \\
\text { distribution of responsibility }\end{array}$ \\
\hline 2 & $\begin{array}{l}\text { Maintaining the chain of } \\
\text { command by defining roles and } \\
\text { responsibility }\end{array}$ & $\begin{array}{l}\text { Could make decision making slow } \\
\text { especially during crisis }\end{array}$ \\
\hline 3 & $\begin{array}{l}\text { Vision and mission shared and } \\
\text { distributed through all of confidence } \\
\text { organisation layers }\end{array}$ & $\begin{array}{l}\text { Could create uncertainty and luck } \\
\text { Encourages productivity, loyalty } \\
\text { and commitment }\end{array}$ \\
\hline 5 & $\begin{array}{l}\text { Decision making is subjective to } \\
\text { arguments due to the number of } \\
\text { voices }\end{array}$ \\
\hline 6 & $\begin{array}{l}\text { Mutual and upward learning } \\
\text { curve }\end{array}$ & \\
\hline 7 & Equal opportunity to contribute \\
\hline
\end{tabular}

Distributed Leadership "is an idea that can be traced back as far as the mid-20s earlier" (Harris, 2009, p.3) as it became an area and topic embraced by researchers and practitioners in the turn of the $2 \mathrm{I}^{\text {st }}$ century. Distributed leadership is what is also called collective leadership or collaborative leadership. Distributed leadership is not about an individual rather than people whom this individual is collectively working and interacting with. In other words, where individuals collectively operate creating greater value than one person can.

At the organizational level, senior leadership or the person on top simply can no longer deal solely with all complex economic environment and the organizational complexity. Distributed Leadership is about assembling a complete systematic process that collectively encourages the creation of innovative leaders that are able to lead different transformation initiatives within the organizational boundaries. In organizational mindset, distributed leadership is a shift from command, control and authority leadership to more collective, coordinative and collaborative leadership approach. Distributed leadership does not mean organizations does not have a top leader to the contradictory it identifies different leaders from different organizational layers with different expertise and skills carrying out formal \& informal leadership roles that are needed in different stages of the organizational change initiatives. There is enough available evidence that proves Distributed leadership to be an interdependent element and contributor to improved organizational performance.

\subsubsection{Complexity Leadership}

Top-down or what is known as traditional hierarchal has been the preferred leadership model in the last century or, so which has been proved to be very effective for economies and market environment that are mostly depending on physical production. However, with the shift from and industrial age to a more knowledge and information era managerial top-down leadership is becoming unsuitable. Despite the reality that leadership is the main pillar and the ground foundation to successful implementation of organizational transformation and the collective organizational goals achievement, little attention has been given to new knowledge and information era leadership theories which remains an area for research and development. Complexity leadership has arisen from the assumption that organizations now a days are complex and too sophisticated to be led and its goals to be achieved by a single induvial (Uhl-Bien \& Marion, 2009; Lichtenstien et al., 2006). Many scholars and researchers are supporting the argument of that vertical top-down leadership is obsolete in a shifting environment from industrial age to the new knowledge-based economy era. As organizations are expanding and growing in size and turnover they are becoming more complex in their operations, systems and the way business is done (Snowden \& Boone, 2007; Cilliers, I998). 
Such new era creates a new set of challenges and obstacles for organizations and their leadership (McKelvey, 200I; Quinn et al., 2002) which requires them to be more adaptive to changing operational environment, interactive in terms of different organizational components and have an increasing learning curve (Davenport, 200I). As organizations grow and transforms from an era to another newer era organizations becomes more complex not only in their structures and operation, but they become complex in their context (Cilliers, 1998). As its mistakenly understood that complexity is referring to an organization being complicated as stated by contingency theorists in the twentieth century (Buckley, 1967; Perrow, 1972) but complexity is an outcome of the interaction of simplified elements in response to limited information and communications given to them (Cillers, 1998). As complexity leadership originated from complexity science (Snowden \& Boone, 2007). This leadership theory is a study of a complex system with interactive dynamics built in contexts of a greater organizing system. In other words, complexity leadership is a situationally caused by inflated organizational size and organization becoming unable to handle or mange this complexity. The organization becomes unmanageable by a single leader when organizational complexity exceeds induvial complexity (Freytag et al., 2003).

\subsubsection{Democratic Leadership}

Democratic leadership is another construct of team/collective leadership dimension that has been an area of scientific interest in the past few years. This leadership model is common in the educational field as many studies have been conducted in the educational context (Choi, 2007). The fundamental of this construct evolves around the concepts of traditional democratic participative and inclusiveness (Gastil, 1994; Fishkin, I99I; Weinstein et al., I989). Unlike other network leadership constructs democratic leadership don't fully share leadership and responsibility and is formal in its leadership and power execution (Spillane, 2005). Democratic leaders distribute responsibilities amongst team member, assist the group in dissection taking process and empowering group members (Gastil, I994).

Table 5. democratic leadership advantages and disadvantages

\begin{tabular}{llll}
\hline \multicolumn{2}{l}{ Advantage } & Disadvantage \\
\hline I & $\begin{array}{l}\text { Empower leaders to work } \\
\text { with their teams }\end{array}$ & Delays in consensus \\
\hline 2 & $\begin{array}{l}\text { Macro instead of micro } \\
\text { manging }\end{array}$ & Can create a since of ambiguity \\
\hline 3 & $\begin{array}{l}\text { Enhances team collaboration } \\
\text { and bonds }\end{array}$ & Might not take the best decision \\
\hline 4 & Encourages transparency & $\begin{array}{l}\text { Leaders are not accountable especially } \\
\text { in failure }\end{array}$ \\
\hline 5 & $\begin{array}{l}\text { Boost self-stem and job } \\
\text { satisfaction }\end{array}$ & \\
\hline 6 & $\begin{array}{l}\text { Increases } \\
\text { knowledge }\end{array}$ & collective & \\
\hline
\end{tabular}

\subsubsection{Intergroup Leadership}

Intergroup leadership is another network constructs a one that is less famous construct of network leadership spectrum. This leadership style is a new network leadership construct that has not received much interest from scholars and researchers unlike other constructs mentioned earlier. Intergroup leadership is built around the idea of context inter-organizational importance and the collaboration of each component of the organization (Hogg et al., 2012). Intergroup leadership is a collaboration cooperation of several formal organizational groups (Richter et al., 2006).

\subsubsection{Collaborative Leadership}

Collaborative leadership is another new and under researched network leadership constructs which is embraced with shared leadership. As researchers and scholars admits that participation and leading the organization in full or partial is expected from all organization members (Morse, 2008; Raelin, 2006). The concept of collaborative leadership style is sharing leadership and responsibility amongst a group of members that are ready and competent to take over leadership responsibilities (Zander $\&$ Zander, 2017) where a designated focal leader is willing and ready to share authority and power of leadership. This area of network leadership remains a new area and still needs to be researched and tested both quantitively and qualitatively (Kramer \& Crespy, 201 I). 


\subsubsection{Collective Leadership}

The origin of collective leadership is traced back to Gibb 1954, but has become of more importance to scholars in past 20 years (Pearce \& Conger, 2003). Collective leadership is defined as "a dynamic process in which a defined leader, or set of leaders, selectively utilizes the skills and expertise within a network as the need arises" (Friedrich et al., 2009). Collective leadership is one of the collectivistic approaches to leadership theories and area of growing appetite for scholars and researchers to study (Sergi et al., 2012). When viewing the collective leadership literature, it was noted that there were two different views and schools of thought for such approach. The first, believes and supports the collectivistic approach main concept of a designated focal leader shares, empowers authority and distribute leadership roles within a team or a network of teams (Yammarino et al., 2013). The other, doesn't accept and rejects the whole concept of having a designated focal leader that is willing and is ready to share leadership and supports the idea of full fledge sharing of responsibility and leadership between team or network members (Contractor et al., 2012; Hiller et al., 2006). This research supports both schools of thoughts as collective leadership and collectivistic approach to leadership praises a very broad-spectrum leadership from team to networks and operates in different sectors, which leads to conclusion that amount of power delegation and leadership sharing in circumstantial.

\subsubsection{Participative Leadership}

Participative leadership concept is roots back to Platt 1947 its recently becoming an area of interest to scholars and researchers. Participative leadership is an approach to leadership encouraging and empowering the participation in leadership and decision making by involving group, teams and induvial in problem solving process alongside full participation in day to day organizational management (Bass \& Stohdill, I990; Huang, 20I2). The presence of a designated focal leader is critical in this leadership approach to coordinate the participation of induvial, teams and groups in organizational manegment activities (Long et al., 2012; Lam et al., 2015).

\subsection{Social Network Theory}

Social network theory is a socially assembled structure created by a number of actors such as social, dyadic. Social network theory is way to study the relationship between different components and elements of societies, induvial, organizations, and groups. Social structures and the ties through which units within those structures interact and connect to each other are termed as social network theory (Wasserman \& Faust, 1994). The principle of this theoretical approach in understanding the social interaction between social units is through understanding, studying, and investigating the characteristics of the relational ties between actors(units) rather than actors' characteristics (Borgatti et al., 2009). Social networks are self-organized, emergent, and complex which makes global coherent pattern emerge from the local interaction of actors that creates the social network structure (Scott \& Carrington, 20II; Newman et al., 201I). Those patterns become more visible as networks expand. Social networks are analyzed on three levels in which those network falls (micro, meso and macro).

Organization members focus their activities in their own groups and units suffocating creativity and limiting opportunities. It is important to note that organizational structure loopholes that are detected by organizational network leaders who bridges those wholes has the opportunity of identifying developing opportunities (Burt, 2004). Those network leaders are able to utilize and capitalize on their social abilities acting as informational brokers between different groups that are not in contact providing exposure to ideas, opportunities and opinions (Shirado \& Christakis, 2017). Efficient team leadership is one of the most influential tools of effective teams with high performance and is effective in implementing change during organizational transformation (Mathieu et al., 2008). Therefore, organizations are focusing on building social capital and enhancing overall capacity of its employees (Day et al., 20I4) by expanding beyond the focus on single leaders who will be limited in his influence and effectiveness to more collective and shared leadership between members of the network for better exposure and influence through social context. Looking at leadership from a social network theory approach allows for reciprocal influence examination patterns of ties through networks or group members (D’Innocenzo et al., 2016) and analyzing those relationships in terms of nodes and ties. Whereas the pattern of leadership is described by density and centrality which explains how leadership is centralized around a specific focal point and is helpful tool in understating the role of leaders within the network as well as the entire network. As network density gages the number of ties that the network has in comparison with all achievable ties (Kenny et al., 2006).

\subsection{Actor Network Theory}

The actor network theory is a theocratical approach to social theory that is constructive in its approach and states that human and nonhuman elements have identical influence on the emergence of the social-ecological systems by enacting relations and enrolling other actors (Latour, 2005). Actor network theory looks at organizations as diversified actors brought together in wellconstructed partnership that depends on the ability of those actors to interact with each other. The term actor is not limited to humans as it could be referred to any element of the organization wither human or nonhuman (Law, I99I). Actor network theory states that do not exist by themselves and it should describe rather than explain or analyze social phenomena and 
activities. The term network is controversial in its nature as it has a number of unfavorable interruptions (Latour, 2005). Actor network theory explains material-semiotic networks interact with each other to act as a whole.

\section{Conclusion and Conceptual Model}

This chapter critically reviewed literature related to organizational transformation throws all its forms. Organisational transformation as discussed in this chapter stated the importance of leadership as a main pillar in the achievement of organizational goals and proper implementation of transformation initiatives (Kempster et al., 2014; Gaub et al., 2016). Leadership theory was critically reviewed in a chronological sequence to understand the evolvement of leadership theory from the era of traditional leadership to todays' team/collective leadership theory. As discussed, this research identified and discussed what this research refers to as the team/leadership theory dimensional constructs.

This research is in the area of change management/transformation and leadership. Social network theory \& Actor network theory looked at as potential underpinning theories and the foundation to find out more about leadership from a social aspect. As distributed leadership and organizations transformation/ change management are both looked at and studied by practitioners, researchers separately. However, this research will study how distributed leadership and organizational transformation initiatives intersect and interact with each other and these intersection outcomes could lead to the understanding of what is called network leadership. Distributed leadership states that different leaders assume leadership of teams or networks of leaders in different situations and circumstances depending on the status of the Transformation initiative taken by the organization. In other words, distributed leadership highlights the importance of having the suitable leader in situation that could be fulfilled by that leader regardless of his sequence the organizational chain of command. Where organizational transformation highlights the importance of leadership in general but does not specify which leader in what situation. This intersection between distributed leadership and organizational transformation engages series off leaders involved and this transformation initiative. As these leaders have different leadership roles and positions together they form a network of leaders. Social network theory is used in this research as underpinning theory to understand how this network of leaders operates and evolves with time. Leadership network is not still and evolves overtime depending on the stage and status of the transformation. The ability of an organization to identify leaders and creates networks from those leaders to allow those networks to evolve overtime that's what's successful transformation initiative is. The aim of this research is to study distributed leadership and organizational transformation and investigate the intersection of distributed leadership and organization transformation and what outcomes is expected from such intersection. This research paper demonstrated criteria review of the current literature which led to development of a conceptual model. Which in other if proven to be successful could be the foundation and the pillar of network leadership?

The conceptual model was developed after reviewing the existing organizational transformation, leadership and social network theory literature. The intersection between organizational transformation literature and distributed leadership literature using social network leadership theory to look at how induvial and network interact with each other revealed a connection between organizational transformation literature and leadership literature. One of the dimensions of this intersection of those two important organizational management topics is what this research refers to as network leadership. There was little research and literature looking at organizational transformation and team/collective leadership theory. It was proved by evidence that leadership is considered an important factor in the successful implementation of transformation initiatives. However, it does not specify which type of leaders, leadership styles and in what stage or time of the transformation process. Where leadership literature reviewed stated that distributed leadership is looked at as an initiator of change that by creating groups of individuals that share and distribute leadership roles during different times and circumstances. Figure 3 below explains this conceptual model clearly.

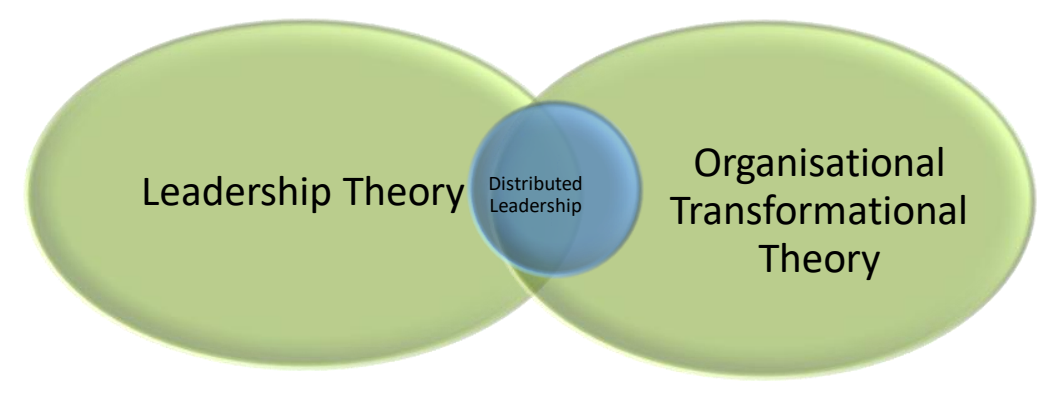

Figure 3. Conceptual Model 
As mentioned above the proposed conceptual model shows that distributed leadership literature states that leadership is an important element and one of the pillars for organizational change implementation during transformation initiatives. Organisational transformation literature also states the importance of leadership during transformational phase. However, organizational transformation literature does not specify which leadership style and at what time and stage of the transformation stage.

As a result, an intersectional relation in noticed between leadership literature and organizational transformation literature. This research assumes that network leadership is one of the dimensions of this intersection and reciprocal relation between the two subjects. This research is proposed to investigate the above mentioned conceptual model through qualitative methodology which is expected to provide a better understanding to researchers as well as add to the existing knowledge.

\section{References}

Arredondo Trapero, F. G., Maldonado de Lozada, V. D. C., \& de la Garza García, J. (2010). Consumers and their buying decision making based on price and information about corporate social responsibility (csr): Case study: Undergraduate students from a private university in Mexico. Estudios Gerenciales, 26(II7), I03-II8.

Aldhaen, E. S. (2017). Study of the strategic decision making process in higher education institutions (Doctoral dissertation, Brunel University London).

AlGhanem, N., Braganza, A., \& Eldabi, T. (2019). Plural Leadership During Organisational Transformation Initiatives (Vertical \& Horizontal). KnE Social Sciences, 90-I08.

Avolio, B. J., Jung, D. I., Murry, W., \& Sivasbramaniam, N. (I996). Building highly developed teams: Focusing on shared leadership process, efficacy, trust, and performance.

Avolio, B. J., Walumbwa, F. O., \& Weber, T. J. (2009). Leadership: Current theories, research, and future directions. Annual review of psychology, 60, 42I-449.

Badaracco, J. (200I). We don't need another hero. Harvard Business Review, 79(8), I20-I26.

Bartunek, J. M., \& Louis, M. R. (I988). The Design of Work Environments to Stretch Managers' Capacities for Complex Thinking. Human Resource Planning, II (I).

Bass, B. M., \& Riggio, R. E. (2006). Transformational leadership. Psychology press.

Bass, B. M., \& Avolio, B. J. (I994). Shatter the glass ceiling: Women may make better managers. Human resource management, 33(4), 549-560.

Bass, B. M., \& Stogdill, R. M. (1990). Bass \& Stogdill's handbook of leadership: Theory, research, and managerial applications. Simon and Schuster.

Beckhard, R. (2006). The healthy organization. Organizational Development, 950-952.

Bennett, N., Wise, C., Woods, P., \& Harvey, J. (2003). Distributed Leadership. Full report, National College for School leadership.

Bolden, R. (2007). Distributed leadership. University of Exeter.

Borgatti, S. P., Mehra, A., Brass, D. J., \& Labianca, G. (2009). Network analysis in the social sciences. science, 323(59I6), 892895.

Bowers, D. G., \& Seashore, S. E. (I966). Predicting organizational effectiveness with a four-factor theory of leadership. Administrative Science Quarterly, 238-263.

Brown, S. L., \& Eisenhardt, K. M. (1997). The art of continuous change: Linking complexity theory and time-paced evolution in relentlessly shifting organizations. Administrative science quarterly, I-34.

Bryk, A., \& Schneider, B. (2002). Trust in schools: A core resource for improvement. Russell Sage Foundation.

Bryson, L., \& Thompson, F. (1978). Reflections on an Australian newtown. In Inside the Whale (pp. 93-I20). Pergamon.

Buckley, W. (I967). Sociology and modern systems theory.

Burt, R. S. (2004). Structural holes and good ideas. American journal of sociology, IIO(2), 349-399.

Carson, J. B., Tesluk, P. E., \& Marrone, J. A. (2007). Shared leadership in teams: An investigation of antecedent conditions and performance. Academy of management Journal, 50(5), I2I7-I234.

Carter, D. R., DeChurch, L. A., Braun, M. T., \& Contractor, N. S. (2015). Social network approaches to leadership: An integrative conceptual review. Journal of Applied Psychology, IOO(3), 597.

Choi, S. (2007). Democratic leadership: The lessons of exemplary models for democratic governance. International Journal of Leadership Studies, 2(3), 243-262.

Cilliers, P. (1998). Complexity and postmodernism: Understanding complex systems. London: Routledge.

Cirre, C. M., Berenguel, M., Valenzuela, L., \& Klempous, R. (2009). Reference governor optimization and control of a distributed solar collector field. European Journal of Operational Research, I93(3), 709-7I7.

Contractor, N. S., DeChurch, L. A., Carson, J., Carter, D. R., \& Keegan, B. (2012). The topology of collective leadership. The Leadership Quarterly, 23(6), 994-IOI I. 
Currie, G., Grubnic, S., \& Hodges, R. (20II). Leadership in public services networks: Antecedents, process and outcome. Public administration, 89(2), 242-264.

Davenport, T. H. (200I). Knowledge work and the future of management. The future of leadership: Today's top leadership thinkers speak to tomorrow's leaders, 4I-58.

Day, D. V., \& O'Connor, P. M. (2003). Leadership development: Understanding the process. The future of leadership development, II-28.

Day, D. V., Fleenor, J. W., Atwater, L. E., Sturm, R. E., \& McKee, R. A. (2014). Advances in leader and leadership development: A review of 25 years of research and theory. The leadership quarterly, 25(I), 63-82.

DeRue, D. S. (20II). Adaptive leadership theory: Leading and following as a complex adaptive process. Research in organizational behavior, 31, I25-I50.

Detert, J. R., \& Burris, E. R. (2007). Leadership behavior and employee voice: Is the door really open?. Academy of management journal, $50(4), 869-884$.

D’Innocenzo, L., Mathieu, J. E., \& Kukenberger, M. R. (2016). A meta-analysis of different forms of shared leadership-team performance relations. Journal of Management, 42(7), I964-I99I.

Eberly, M. B., Johnson, M. D., Hernandez, M., \& Avolio, B. J. (2013). An integrative process model of leadership: Examining loci, mechanisms, and event cycles. American Psychologist, 68(6), 427.

Ensley, M. D., Hmieleski, K. M., \& Pearce, C. L. (2006). The importance of vertical and shared leadership within new venture top management teams: Implications for the performance of startups. The leadership quarterly, I7(3), 2I7-23I.

Erez, A., Lepine, J.A. and Elms, H. (2002). Effects of rotated leadership and peer evaluation on the functioning and effectiveness of self-managed teams: a quasi-experiment. Personal Psychology, 55, pp. 929-948.

Fausing, M. S., Jeppe Jeppesen, H., Jønsson, T. S., Lewandowski, J., \& Bligh, M. C. (2013). Moderators of shared leadership: work function and team autonomy. Team Performance Management: An International Journal, I9(5/6), 244-262.

Feldman, M. S., \& Pentland, B. T. (2003). Reconceptualizing organizational routines as a source of flexibility and change. Administrative science quarterly, 48(I), 94-I I8.

Fishkin, J. S. (I99I). Democracy and deliberation: New directions for democratic reform (Vol. 217). New Haven, CT: Yale University Press.

Fitzgerald, I., Ferlie, E., Mcgivern, G. and Buchanan, D. (2013). Distributed leadership patterns and service improvement: evidence and arguments from English lealthcare. The Leadership Quarterly, 24(I), 227-239.

Fitzsimons, D., James, K. T., \& Denyer, D. (201 I). Alternative approaches for studying shared and distributed leadership. International Journal of Management Reviews, I3(3), 313-328.

Follet, M. P., Metcalf, H. C., \& Urwick, L. (1925). How must Business Management Develop in Order to Possess the Essentials of a Profession?. Dynamic Administration: The Collected Papers of Mary Parker Follet, I7-3I.

Francis, D., Bessant, J., \& Hobday, M. (2003). Managing Radical Organisational Transformation. Management Decision, $4 I(\mathrm{I}), \mathrm{I} 8-3 \mathrm{I}$.

Freytag, P. V., Wilkinson, I., Young, L., \& Chery, M. C. (2003). Business mating: who chooses whom and gets chosen?. In I9th Annual IMP Conference 2003.

Friedrich, T. E., \& Elias, L. J. (20I4). Behavioural asymmetries on the greyscales task: The influence of native reading direction. Culture and brain, 2(2), I6I-I72.

Friedrich, T. L., Vessey, W. B., Schuelke, M. J., Ruark, G. A., \& Mumford, M. D. (2009). A framework for understanding collective leadership: The selective utilization of leader and team expertise within networks. The Leadership Quarterly, 20(6), 933-958.

Gastil, J. (1994). A definition and illustration of democratic leadership. Human Relations, 47(8), 953-975.

Gaub, J. E., Choate, D. E., Todak, N., Katz, C. M., \& White, M. D. (2016). Officer perceptions of body-worn cameras before and after deployment: A study of three departments. Police quarterly, I9(3), 275-302.

Gronn, P. (2002). Distributed leadership as a unit of analysis. The leadership quarterly, I3(4), 423-45I.

Gronn, P. (2003). The new work of educational leaders: Changing leadership practice in an era of school reform. Sage.

Gronn, P. (2008). The state of Denmark. Joumal of educational administration and history, 40(2), I73-I85.

Gupta, V.K., Huang, R. and Yayla, A. (20II). Social capital, collective transformational leadership, and performance: a resource-based view of self-managed teams. Journal of Managerial Issues, 23, pp.3I-45.

Henderson, R. M., \& Clark, K. B. (1990). Architectural innovation: The reconfiguration of existing product technologies and the failure of established firms. Administrative science quarterly, 9-30.

Harris, A. (2009). Distributed leadership: What we know. In Distributed leadership (pp. I I-2I). Springer, Dordrecht.

Higgs, M., \& Rowland, D. (20II). What does it take to implement change successfully? A study of the behaviors of successful change leaders. The Journal of Applied Behavioral Science, 47(3), 309-335. 
Hiller, N. J., Day, D. V., \& Vance, R. J. (2006). Collective enactment of leadership roles and team effectiveness: A field study. The Leadership Quarterly, I7(4), 387-397.

Hoch, J. E. (2013). Shared leadership and innovation: The role of vertical leadership and employee integrity. Journal of Business and Psychology, 28(2), I59-174.

Hoch, J. E., \& Kozlowski, S. W. (20I4). Leading virtual teams: Hierarchical leadership, structural supports, and shared team leadership. Journal of applied psychology, $99(3), 390-403$.

Hogg, M. A., Van Knippenberg, D., \& Rast III, D. E. (20I2). Intergroup leadership in organizations: Leading across group and organizational boundaries. Academy of Management Review, 37(2), 232-255.

Hollander, E. P., \& Julian, J. W. (I969). Contemporary trends in the analysis of leadership processes. Psychological bulletin, $7 I(5), 387$.

Huang, X. (2012). Helplessness of empowerment: The joint effect of participative leadership and controllability attributional style on empowerment and performance. Human Relations, 65(3), 313-334.

Karimuribo, E. D., Fitzpatrick, J. L., Bell, C. E., Swai, E. S., Kambarage, D. M., Ogden, N. H., ... \& French, N. P. (2006). Clinical and subclinical mastitis in smallholder dairy farms in Tanzania: risk, intervention and knowledge transfer. Preventive veterinary medicine, 74(I), 84-98.

Kenny, D. A., Kashy, D. A., \& Cook, W. L. (2006). Dyadic analysis. New York: Guildford.

Kickert, W. J., Klijn, E. H., \& Koppenjan, J. F. (Eds.). (I997). Managing complex networks: Strategies for the public sector. Sage.

Kramer, M. W., \& Crespy, D. A. (20II). Communicating collaborative leadership. The Leadership Quarterly, 22(5), I024I037.

Kempster, S., Higgs, M., \& Wuerz, T. (2014). Pilots for change: exploring organisational change through distributed leadership. Leadership \& Organization Development Journal.

Lam, C. K., Huang, X., \& Chan, S. C. (2015). The threshold effect of participative leadership and the role of leader information sharing. Academy of Management Journal, 58(3), 836-855.

Latour, B. (2005). Reassembling the Social: An Introduction to Actor-Network-Theory Oxford and New York: Oxford University Press.

Law, J. (Ed.). (I99I). A sociology of monsters: Essays on power, technology, and domination (No. 38). Routledge.

Levene, R. J., \& Braganza, A. (I996). Controlling the work scope in organisational transformation: a programme management approach. International Journal of Project Management, I4(6), 33I-339.

Levine, P., Uhlir, M., \& White, J. (I96I). Ah, an incomplete suppression of A resembling Oh. Vox sanguinis, 6(5), 56 I-567.

Lichtenstein, B. B., Uhl-Bien, M., Marion, R., Seers, A., Orton, J. D., \& Schreiber, C. (2006). Complexity leadership theory: An interactive perspective on leading in complex adaptive systems.

Long, W., Huang, X., \& Lau, D. C. (2012). Leadership research in Asia: Taking the road less traveled?. Asia Pacific Journal of Management, 29(2), 195-204.

Lord, R. G., Brown, D. J., Harvey, J. L., \& Hall, R. J. (200I). Contextual constraints on prototype generation and their multilevel consequences for leadership perceptions. The Leadership Quarterly, I2(3), 3I I-338.

Mathieu, J., Maynard, M. T., Rapp, T., \& Gilson, L. (2008). Team effectiveness 1997-2007: A review of recent advancements and a glimpse into the future. Journal of management, 34(3), 4I0-476.

McKelvey, B. (200I). Emergent strategy via Complexity Leadership: Using complexity science and adaptive tension to build distributed intelligence. Uhl-Bien \& R. Marion (Eds), Comple4xity and leadership volume I: Conceptual foundation. Charlotte, NC: Information Age Publishing.

Mehra, A., Smith, B. R., Dixon, A. L., \& Robertson, B. (2006). Distributed leadership in teams: The network of leadership perceptions and team performance. The Leadership Quarterly, I7(3), 232-245.

Mikalef, P., van de Wetering, R., \& Krogstie, J. (2018, July). Big Data enabled organizational transformation: The effect of inertia in adoption and diffusion. In International Conference on Business Information Systems (pp. I35-I47). Springer, Cham.

Morse, R. S., \& Buss, T. F. (Eds.). (2008). Innovations in public leadership development. ME Sharpe.

Newman, M., Barabasi, A., \& Watts, D.J. (20II) The structure and dynamics of networks. Princeton University Press.

Pawar, B. S., \& Eastman, K. K. (1997). The nature and implications of contextual influences on transformational leadership: A conceptual examination. Academy of management review, 22( I), 80-109.

Pearce, C. L., \& Conger, J. A. (2003). All those years ago. Shared leadership: Reframing the hows and whys of leadership, I-I8.

Perrow, C. (1972). Complex Organisations: A Critical Essay, Scott Foresman. Glenview, Illinois, I I7-I I8.

Perry, M. L., Pearce, C. L., \& Sims Jr, H. P. (I999). Empowered selling teams: How shared leadership can contribute to selling team outcomes. Journal of Personal Selling \& Sales Management, I9(3), 35-5I. 
Quinn, J. B., Anderson, P., \& Finkelstein, S. (2002). Gerenciando o Intelecto Profissional: Obtendo o máximo dos melhores. KLEIN, David. A Gestão Estratégica do Capital Intelectual: Recursos para a economia baseada no conhecimento. Rio de Janeiro: Qualitymark.

Richter, A. W., West, M. A., Van Dick, R., \& Dawson, J. F. (2006). Boundary spanners' identification, intergroup contact, and effective intergroup relations. Academy of Management Journal, 49(6), I252-I269.

Raelin, J. (2006). Does action learning promote collaborative leadership?. Academy of Management Learning \& Education, 5(2), I52-I68.

Ribera, D., Narbonne, J. F., Arnaud, C., \& Saint-Denis, M. (200I). Biochemical responses of the earthworm Eisenia fetida andrei exposed to contaminated artificial soil, effects of carbaryl. Soil Biology and Biochemistry, 33(7-8), II23-I I30.

Scott, J., \& Carrington, P. J. (20I I). The SAGE handbook of social network analysis. SAGE publications.

Seers, A., Keller, T., \& Wilkerson, J. M. (2003). Can team members share leadership. Shared leadership: Reframing the hows and whys of leadership, 77-I02.

Sergi, V., Denis, J. L., \& Langley, A. (2012). Opening up perspectives on plural leadership. Industrial and Organizational Psychology, 5(4), 403-407.

Shirado, H., \& Christakis, N. A. (2017). Locally noisy autonomous agents improve global human coordination in network experiments. Nature, 545(7654), 370-374.

Sivasubramaniam, N., Murry, W.D., Avolio, B.J. and Jung, D.I. (2002). A longitudinal model of the effects of team leadership and group potency on group performance.

Small, E. E., \& Rentsch, J. R. (20II). Shared leadership in teams. Journal of Personnel Psychology.

Snowden, D. J., \& Boone, M. E. (2007). A leader's framework for decision making. Harvard business review, 85(II), 68.

Spillane, J. P. (2005). Primary school leadership practice: How the subject matters. School leadership and management, 25(4), 383-397.

Spillane, J. P. (2012). Distributed leadership (Vol. 4). John Wiley \& Sons.

Uhl-Bien, M., \& Marion, R. (2009). Complexity leadership in bureaucratic forms of organizing: A meso model. The Leadership Quarterly, 20(4), 63 I-650.

Wagner III, J. A., \& Hollenbeck, J. R. (20I4). Organizational behavior: Securing competitive advantage. Routledge.

Wang, D., Waldman, D. A., \& Zhang, Z. (2014). A meta-analysis of shared leadership and team effectiveness. Journal of applied psychology, 99(2), I8I.

Wasserman, S., \& Faust, K. (I994). Social network analysis: Methods and applications (Vol. 8). Cambridge university press.

Weick, K. E., \& Quinn, R. E. (I999). Organizational change and development. Annual review of psychology, 50 (I), 36 I-386.

Weinstein, C. E., Ridley, D. S., Dahl, T., \& Weber, E. S. (I989). Helping students develop strategies for effective learning. Educational Leadership, 46(4), I7-I9.

Wind, M. E. D. (2017). Network leadership: Defining its continuum (Master's thesis, University of Twente).

Wren, D. A., Bedeian, A. G., \& Breeze, J. D. (2002). The foundations of Henri Fayol's administrative theory. Management Decision, 40(9), 906-9I8.

Yammarino, F. J., Mumford, M. D., Serban, A., \& Shirreffs, K. (2013). Assassination and leadership: Traditional approaches and historiometric methods. The Leadership Quarterly, 24(6), 822-84I.

Zander, R.S. \& Zander, B. (2017). The Art of Possibility. Place of publication not identified: Skillsoft Ireland Limited.

Zhou, W. (2012). Moderating and mediating effects of shared leadership on the relationship between entrepreneurial team diversity and performance. Unpublished doctoral dissertation. New York (NY): City University of New York.

\section{Copyrights}

Copyright for this article is retained by the author(s), with first publication rights granted to the journal. This is an open-access article distributed under the terms and conditions of the Creative Commons Attribution license (http://creativecommons.org/licenses/by/4.0/). 